\title{
In vitro Antitumor Activities of Platycarya strobilacea Sieb et Zucc Infructescence Extracts
}

\author{
Liangliang Zhang ${ }^{1,2 *}$, Yongmei Wang ${ }^{1,2}$ and Man $\mathrm{Xu}^{1}$ \\ ${ }^{1}$ Institute of Chemical Industry of Forest Products, Chinese Academy of Forestry, National Engineering Lab. for Biomass \\ Chemical Utilization, Key and Open Lab. of Forest Chemical Engineering, State Forestry Administration, Key Lab. of Biomass \\ Energy and Material, Jiangsu Province, Nanjing 210042, ${ }^{2}$ Institute of New Technology of Forestry, Chinese Academy of \\ Forestry, Beijing 100091, China
}

*For correspondence: Email: zhll20086@163.com; Tel: +86 25 85482463; Fax: +86 2585482463

\begin{abstract}
Purpose: To evaluate the antitumor activities of Platycarya strobilacea infructescence extracts in A549, HepG2, SH-SY-5Y, HCT116, and U2OS-NKFB cell lines.

Methods: The total amount of phenolics in $P$. strobilacea infructescence based on three solvent extracts (methanol, ethyl acetate and water) was measured using Folin-Ciocalteu reagent method. The cytotoxic effect of the various solvent extracts and tannins on five cancerous cell lines (A549, HepG2, $\mathrm{SH}-\mathrm{SY}-5 \mathrm{Y}$, HCT116, and U2OS-NKFB) were assayed using 3-(4,5-dimethylthiazol-2-yl)-2,5diphenyltetrazolium bromide [MTT].

Results: Ethyl acetate extract had the highest phenolic content $(725.02 \mathrm{mg} \mathrm{GAE} / \mathrm{g})$, followed by methanol extract (627.64 mg GAE/g). Among the extracts tested, ethyl acetate extract had effective anticancer activity against A549, HepG2, HCT116 and U2OS-NKFB cells with IC 50 values of 40.1, 42.6, 40.1 and $73.4 \mu \mathrm{g} / \mathrm{mL}$, respectively. Methanol extract had the strongest cytotoxic effect on $\mathrm{SH}-\mathrm{SY}-5 \mathrm{Y}$ cell with $I C_{50}$ value of $31.2 \mu \mathrm{g} / \mathrm{mL}$. The number of surviving cancerous cells decreased as the concentration of the ethyl acetate and methanol extracts increased.

Conclusion: The study confirms the antitumor activities of ethyl acetate and methanol extracts of $P$. strobilacea infructescence. Thus, the plant extracts constitute potential therapeutic materials that require further studies and development.
\end{abstract}

Keywords: Platycarya strobilacea, Antitumor, Phenolic compounds, Tannins, MTT assay

Tropical Journal of Pharmaceutical Research is indexed by Science Citation Index (SciSearch), Scopus, International Pharmaceutical Abstract, Chemical Abstracts, Embase, Index Copernicus, EBSCO, African Index Medicus, JournalSeek, Journal Citation Reports/Science Edition, Directory of Open Access Journals (DOAJ), African Journal Online, Bioline International, Open-J-Gate and Pharmacy Abstracts

\section{INTRODUCTION}

The medicinal value of plants lies in some chemical substances that produce a definite physiological action on the human body. The most important of these bioactive compounds of plants are alkaloids, flavonoids, tannins and phenolic compounds [1]. Plants have an almost limitless ability to synthesize aromatic substances, most of which are phenols or their oxygen-substituted derivatives [2]. Some of these phytochemicals can significantly reduce the risk of cancer due to polyphenol antioxidant and antiinflammatory effects. Some preclinical studies suggest that phytochemicals can prevent colorectal cancer and other cancers [3-5].

Platycarya strobilacea Sieb et Zucc has long been recognized in China as a medicinal plant with a variety of medicinal effects. Its dried infructescence has the function of eliminating toxic heat, activating blood circulation, relieving 
swelling, evacuating pus and removing pain, etc [6]. The main constituents reported from its infructescence are flavones, ellagic acid, tannins and related compounds [7-9], and the type of tannins from this plant belongs to the ellagitannins [8]. It has been reported that ellagic acid and its derivatives that are present in the plant have numerous biological activities such as antioxidative, antimicrobial, antifungal, and antiinflammatory activities [10-12]. However, to our knowledge, no information is available on the antitumor properties of $P$. strobilacea infructescence (PSI) extracts.

In the present study, methanol, ethyl acetate and water extracts of PSI as well as tannins from this plant were studied against five cancer cell lines (A549, HepG2, SH-SY-5Y, HCT116 and U2OSNKFB). It is noteworthy that our study is the first report about cytotoxic activity of $P$. strobilacea infructescence.

\section{EXPERIMENTAL}

\section{Plant materials}

$P$. strobilacea infructescence was obtained from Lianyungang, Jiangsu province in August 2012, and authenticated by Professor Jiahong Chen, Institute of Chemical Industry of Forest Products, CAF. A voucher specimen was deposited in the herbarium of our laboratory (ICIFP no. 121). The infructescence was washed with sterile water, dried in shade, finely powdered and stored in air tight plastic bags.

\section{Preparation of plant extract and fractions}

Plant material $(200 \mathrm{~g})$ was extracted with petroleum ether at room temperature for $10 \mathrm{~h}$. After drying, defatted plant material $(190 \mathrm{~g})$ was extracted with $700 \mathrm{~mL}$ of $70 \%(\mathrm{v} / \mathrm{v})$ aqueous methanol in a shaker bath set at $40{ }^{\circ} \mathrm{C}$ for $1 \mathrm{~h}$ and filtered. This extraction step was repeated three times. The filtrates were combined and methanol was evaporated under vacuum at 45 ${ }^{\circ} \mathrm{C}$ using a rotary evaporator and the aqueous phase was lyophilized to obtain methanol extract. The methanol extract was dissolved in $200 \mathrm{~mL}$ of water and extracted with $200 \mathrm{~mL}$ ethyl acetate three times. The ethyl acetate phases were combined and evaporated under vacuum at 40 ${ }^{\circ} \mathrm{C}$ using a rotary evaporator until dryness to give a yield of $7.10 \mathrm{~g}$. The aqueous phase remaining after ethyl acetate extraction was lyophilized to give a yield of $26.5 \mathrm{~g}$. Each extract was refrigerated for further experiments. Yields of extracted matter were calculated as percentage $(w / w)$ of plant material.

\section{Preparation of tannin polymers}

The process of water-extraction and macroporous resin adsorption was adopted to separate and purify tannin polymers. Plant material $(80 \mathrm{~g})$ was extracted with $500 \mathrm{~mL}$ water twice at $80{ }^{\circ} \mathrm{C}$ for $1 \mathrm{~h}$. The extract was filtered and pooled, and the extract was concentrated by vacuum evaporation at $55^{\circ} \mathrm{C}$ to $1 / 4$ of its original volume. The crude tannins extract was adsorbed with NKA-9 macroporous resin which was first eluted with $1 \mathrm{~L} 10 \%$ methanol solution (v/v) to remove oligomeric tannins and then followed by $600 \mathrm{~mL}$ methanol solution. The last fraction, containing the tannin polymers, was vacuumevaporated to remove solvent and freeze-dried to obtain $3.552 \mathrm{~g}$ tannin polymer fraction.

\section{Determination of molecular weight distribution of tannin polymers}

Gel permeation chromatography (GPC) analysis was performed with Waters 1515 GPC equipment. The column used was an Aglient PI aquagel $\mathrm{OH}-30(7.5 \mathrm{~mm} \times 300 \mathrm{~mm}, 5 \mu \mathrm{m})$ column. Tetrahydrofuran (THF) was used as the eluent, and the conditions used were as follows: flow rate, $1 \mathrm{~mL} / \mathrm{min}$; column temperature, $30{ }^{\circ} \mathrm{C}$; injection volume, $25 \mu \mathrm{L}$; and detection occurred at $270 \mathrm{~nm}$, with a bandwidth of $15 \mathrm{~nm}$. The calibration curve was obtained with polystyrene standards. The tannin polymers were dissolved in THF ( $4 \mathrm{mg} / \mathrm{mL})$ and analysed by GPC.

\section{Evaluation of total phenolic compounds}

The amount of total phenolics in the various PSI various solvent extracts was measured using the Folin-Ciocalteu reagent method described by Djeridane et al [13]. The final results were expressed as gallic acid equivalents (GAE) in $\mathrm{mg}$ per g extract.

\section{Cell lines}

Five tumor cell lines, A549 (non-small cell line carcinoma), HepG2 (hepatocellular carcinoma), SH-SY-5Y (human neuroblastoma), HCT116 (human colon cancer) and U2OS-NKFB (human osteosarcoma) were obtained from the laboratory of pharmacology, China Pharmaceutical University, Nanjing, China. All cell lines were grown in suitable media supplemented with $10 \%$ fetal bovine serum

\section{MTT assay}

MTT (3-(4,5-dimethylthiazol-2-yl)-2,5-diphenyltetrazolium bromide) colorimetric assay is used 
to assess cell viability in the presence of different extracts [14]. Cells were seeded into 96-well plates and incubated for $24 \mathrm{~h}$ at $37^{\circ} \mathrm{C}$. Then the medium was replaced with fresh medium containing different concentrations of test extracts. After $72 \mathrm{~h}$ incubation at $37{ }^{\circ} \mathrm{C}$, the medium was changed with fresh medium containing MTT and incubated for additional $4 \mathrm{~h}$. Thereafter, MTT was removed and the remaining formazan crystals were completely dissolved in DMSO. Afterwards, the absorbance was recorded at $570 \mathrm{~nm}$, using an ELISA reader. Inhibitory rate was calculated using Eq 1.

Inhibitory rate $(\%)=\{1-(\mathrm{At} / \mathrm{Ac})\} 100$

where At and Ac are the absorbance of test sample and control, respectively.

$\mathrm{IC}_{50}$ value was defined as the concentration of the extract to produce a $50 \%$ reduction in viability of cells relative to the negative control (wells exposed to the solvent without any extract). All experiments were performed in triplicate.

\section{Statistical analysis}

The statistical analyses were performed by a one-way ANOVA and the Duncan's multiple range test. The results were expressed as means $\pm S D$ to show variations in the various experiments. The statistical package, SPSS (version 11.0, SPSS Institute, Chicago, IL, USA) was used for the analysis. Difference of $p<0.05$ was considered to be significant.

\section{RESULTS}

The PSI was extracted in methanol and subjected to solvent-solvent partitioning to yield two fractions as ethyl acetate and water. The yield of ethyl acetate fraction $(3.55 \%)$ was much lower than that of water fraction (13.25\%). The total phenolic content of each extract was quantified. The phenolic contents in the different extracts also varied significantly $(p<0.05)$. The ethyl acetate fraction had the highest phenolic content (725.02 $\mathrm{mg} \mathrm{GAE} / \mathrm{g}$ ), followed by the methanol extract (627.64 $\mathrm{mg}$ GAE/g) and the water extract (546.37 mg GAE/g).

The molecular weight distribution of the PSI tannins was obtained by Gel Permeation chromatography (GPC). It was characterized by the presence of high molecular weight species
(Figure 1). The values of the number-average molecular weight (Mn), weight-average molecular weight $(\mathrm{Mw})$ and polydispersity $(\mathrm{D}=\mathrm{Mw} / \mathrm{Mn})$ of the tannin polymer fraction are 1275,1545 and 1.212 , respectively.

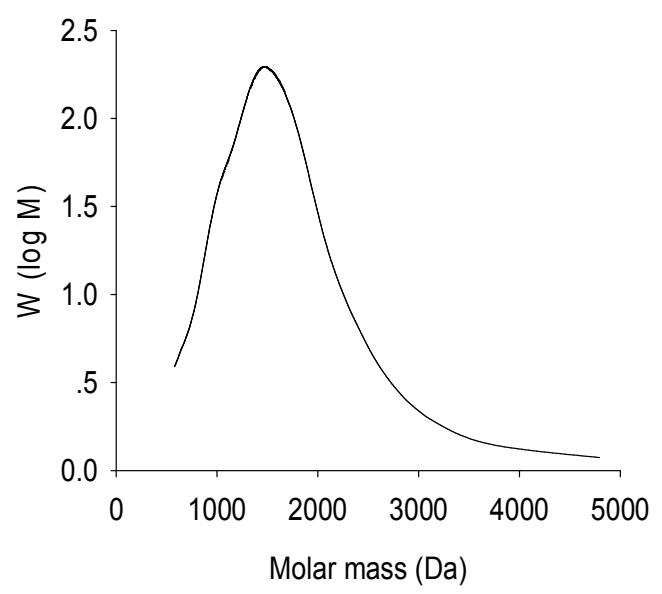

Figure 1: Molecular weight distribution of $P$. strobilacea infructescence tannins

The antitumor activities of the various solvent extracts and tannins of PSI showed significant variations as shown in Tables 1 - 5. A549, HepG2, HCT116 and U2OS-NKFB cells were treated with various solvent extracts and tannins at concentrations ranging from 10 to $160 \mu \mathrm{g} / \mathrm{mL}$ for $72 \mathrm{~h}$ at $37^{\circ} \mathrm{C}$ and then the percentage of cell viability was calculated. SH-SY-5Y cell was treated with water, ethyl acetate, methanol extracts and tannins at concentrations of 10 160, 15 - 240, 10 - 160 and $25-400 \mu \mathrm{g} / \mathrm{mL}$, respectively. The tested malignant cells showed a good response to the effect of ethyl acetate and methanol extracts. Ethyl acetate fraction at 10-160 $\mathrm{\mu g} / \mathrm{mL}$ decreased the proliferation of A549, HepG2, HCT116 and U2OS-NKFB cells by $18.4-87.6 \%, 14.9-87.7 \%, 15.5-95.5 \%$ and $19.4-79.4 \%$, respectively. The $\mathrm{IC}_{50}$ values of the four malignant cells were 40.1, 42.6, 40.1 and $73.4 \mu \mathrm{g} / \mathrm{mL}$, respectively (Figure 2). Also, the methanol extract had the strongest cytotoxic effect on SH-SY-5Y cell. The percentage of dead SH-SY-5Y cell was $86.3 \%$, after exposure to 160 $\mu \mathrm{g} / \mathrm{mL}$ of the methanol extract (Table 5). The $\mathrm{IC}_{50}$ for SH-SY-5Y cell viability was $31.2 \mu \mathrm{g} / \mathrm{mL}$. Compared to the above extracts, water and tannin fractions exerted lower cytotoxic effect on HCT116 and U2OS-NKFB cells as they showed lower degrees of cell death. 
Table 1: Anticancer activity of different concentrations of various $P$. strobilacea infructescence solvent extracts and tannins on A549 cell line

\begin{tabular}{|c|c|c|c|c|c|c|c|c|}
\hline \multirow[t]{2}{*}{ Conc } & \multicolumn{2}{|l|}{ WF } & \multicolumn{2}{|c|}{ EF } & \multicolumn{2}{|c|}{ MF } & \multicolumn{2}{|l|}{ TF } \\
\hline & $O D_{570 \mathrm{~nm}}$ & Inhi & $O D_{570 \mathrm{~nm}}$ & Inhi & $O D_{570 \mathrm{~nm}}$ & Inhi & $O D_{570 \mathrm{~nm}}$ & Inhi \\
\hline Control & $0.65 \pm 0.05$ & nil & $0.65 \pm 0.05$ & nil & $0.51 \pm 0.04$ & nil & $0.56 \pm 0.06$ & nil \\
\hline 10 & $0.59 \pm 0.03$ & 10.0 & $0.53 \pm 0.06^{* \star}$ & 18.4 & $0.49 \pm 0.05$ & 2.8 & $0.47 \pm 0.01^{*}$ & 16.3 \\
\hline 20 & $0.58 \pm 0.04^{*}$ & 11.8 & $0.44 \pm 0.06^{* *}$ & 32.9 & $0.48 \pm 0.02$ & 5.8 & $0.43 \pm 0.01^{*}$ & 23.2 \\
\hline 40 & $0.55 \pm 0.05^{* *}$ & 15.9 & $0.49 \pm 0.07^{\star \star}$ & 25.4 & $0.43 \pm 0.03^{*}$ & 16.1 & $0.41 \pm 0.02^{* *}$ & 25.9 \\
\hline 80 & $0.33 \pm 0.07^{* *}$ & 49.3 & $0.11 \pm 0.04^{\star *}$ & 83.8 & $0.29 \pm 0.05^{* *}$ & 42.6 & $0.19 \pm 0.05^{\star \star}$ & 66.7 \\
\hline 160 & $0.08 \pm 0.03^{* *}$ & 88.2 & $0.08 \pm 0.06^{* *}$ & 87.6 & $0.12 \pm 0.02^{* *}$ & 77.0 & $0.09 \pm 0.04^{* *}$ & 84.5 \\
\hline
\end{tabular}

Key: Conc = concentration $(\mu \mathrm{g} / \mathrm{mL}) ;$ Inhi = inhibition (\%); Values are means $\pm S D(n=6),{ }^{*} p<0.05$ vs control, ${ }^{* *} p$ $<0.01$ vs control; $W F=$ water fraction; $E F=$ ethyl acetate fraction; $M E=$ methanol extract; $T F=$ tannin fraction

Table 2: Anticancer activity of different concentrations of various $P$. strobilacea infructescence solvent extracts and tannins on HepG2 cell line

\begin{tabular}{|c|c|c|c|c|c|c|c|c|}
\hline \multirow[t]{2}{*}{ Conc } & \multicolumn{2}{|l|}{ WF } & \multicolumn{2}{|c|}{ EF } & \multicolumn{2}{|c|}{ MF } & \multicolumn{2}{|l|}{ TF } \\
\hline & $O D_{570 \mathrm{~nm}}$ & Inhi & $O D_{570 \mathrm{~nm}}$ & Inhi & $O D_{570 \mathrm{~nm}}$ & Inhi & $O D_{570 \mathrm{~nm}}$ & Inhi \\
\hline Control & $0.66 \pm 0.05$ & nil & $0.66 \pm 0.05$ & nil & $0.66 \pm 0.05$ & nil & $0.64 \pm 0.02$ & nil \\
\hline 10 & $0.60 \pm 0.03$ & 9.6 & $0.56 \pm 0.03^{* *}$ & 14.9 & $0.56 \pm-.07^{*}$ & 14.8 & $0.59 \pm 0.01^{* *}$ & 8.1 \\
\hline 20 & $0.59 \pm 0.04^{*}$ & 11.4 & $0.47 \pm 0.06^{\star *}$ & 29.3 & $0.47 \pm 0.02^{* *}$ & 28.4 & $0.52 \pm 0.05^{\star *}$ & 18.5 \\
\hline 40 & $0.56 \pm 0.05^{\star}$ & 15.4 & $0.46 \pm 0.05^{\star *}$ & 30.6 & $0.39 \pm 0.03^{* *}$ & 40.6 & $0.39 \pm 0.02^{\star *}$ & 39.0 \\
\hline 80 & $0.34 \pm 0.06^{\star *}$ & 48.9 & $0.15 \pm 0.04^{* *}$ & 77.9 & $0.27 \pm 0.01^{* \star}$ & 58.8 & $0.31 \pm 0.04^{* *}$ & 51.0 \\
\hline 160 & $0.09 \pm 0.03^{\star *}$ & 87.1 & $0.08 \pm 0.06^{\star *}$ & 87.7 & $0.17 \pm 0.01^{\star *}$ & 74.3 & $0.28 \pm 0.02^{\star *}$ & 56.8 \\
\hline
\end{tabular}

Key: Conc = concentration $(\mu \mathrm{g} / \mathrm{mL}) ;$ Inhi = inhibition (\%); Values are means $\pm S D(n=6),{ }^{*} p<0.05$ vs control, ${ }^{* *} p$ $<0.01 \mathrm{vs}$ control; $W F=$ water fraction; $E F=$ ethyl acetate fraction; $M E=$ methanol extract; $T F=$ tannin fraction

Table 3: Anticancer activity of different concentrations of various $P$. strobilacea infructescence solvent extracts and tannins on HCT116 cell line

\begin{tabular}{|c|c|c|c|c|c|c|c|c|}
\hline \multirow[t]{2}{*}{ Conc } & \multicolumn{2}{|l|}{ WF } & \multicolumn{2}{|c|}{ EF } & \multicolumn{2}{|c|}{ MF } & \multicolumn{2}{|l|}{ TF } \\
\hline & $O D_{570 \mathrm{~nm}}$ & Inhi & $O D_{570 \mathrm{~nm}}$ & Inhi & $O D_{570 \mathrm{~nm}}$ & Inhi & $O D_{570 \mathrm{~nm}}$ & Inhi \\
\hline Control & $1.31 \pm 0.11$ & nil & $1.31 \pm 0.11$ & nil & $1.31 \pm 0.11$ & nil & $1.31 \pm 0.11$ & nil \\
\hline 10 & $1.22 \pm 0.14$ & 7.0 & $1.11 \pm 0.15$ & 15.5 & $1.12 \pm 0.13^{*}$ & 14.7 & $1.29 \pm 0.12$ & 15.0 \\
\hline 20 & $1.19 \pm 0.11$ & 9.1 & $1.04 \pm 0.17^{*}$ & 20.3 & $0.88 \pm 0.09^{* *}$ & 32.6 & $1.01 \pm 0.16^{*}$ & 23.1 \\
\hline 40 & $1.10 \pm 0.08$ & 16.3 & $0.93 \pm 0.15^{\star *}$ & 28.9 & $0.88 \pm 0.22^{* *}$ & 33.0 & $0.87 \pm 0.11^{* *}$ & 33.3 \\
\hline 80 & $1.01 \pm 0.07^{\star}$ & 23.1 & $0.17 \pm 0.18^{\star *}$ & 86.7 & $0.41 \pm 0.13^{* *}$ & 69.0 & $0.84 \pm 0.16^{* *}$ & 35.9 \\
\hline 160 & $0.59 \pm 0.05^{* *}$ & 55.0 & $0.06 \pm 0.16^{* *}$ & 95.5 & $0.30 \pm 0.12^{* *}$ & 77.0 & $0.80 \pm 0.12^{\star *}$ & 39.2 \\
\hline
\end{tabular}

Key: Conc = concentration $(\mu \mathrm{g} / \mathrm{mL})$; Inhi = inhibition (\%); Values are means $\pm S D(n=6),{ }^{*} p<0.05$ vs control, ${ }^{* *} p$ $<0.01$ vs control; $W F=$ water fraction; $E F=$ ethyl acetate fraction; $M E=$ methanol extract; $T F=$ tannin fraction

Table 4: Anticancer activity of different concentrations of various $P$. strobilacea infructescence solvent extracts and tannins on U2OS-NKFB cell line

\begin{tabular}{|c|c|c|c|c|c|c|c|c|}
\hline \multirow[t]{2}{*}{ Conc } & \multicolumn{2}{|l|}{ WF } & \multicolumn{2}{|c|}{ EF } & \multicolumn{2}{|c|}{ MF } & \multicolumn{2}{|l|}{ TF } \\
\hline & $O D_{570 \mathrm{~nm}}$ & Inhi & $O D_{570 \mathrm{~nm}}$ & Inhi & $O D_{570 \mathrm{~nm}}$ & Inhi & $O D_{570 \mathrm{~nm}}$ & Inhi \\
\hline Control & $1.31 \pm 0.10$ & nil & $1.31 \pm 0.10$ & nil & $1.31 \pm 0.10$ & nil & $1.31 \pm 0.10$ & nil \\
\hline 10 & $1.23 \pm 0.08$ & 6.6 & $1.06 \pm 0.14$ & 19.4 & $1.10 \pm 0.12$ & 15.8 & $1.28 \pm 0.11$ & 2.7 \\
\hline 20 & $1.18 \pm 0.15$ & 9.7 & $1.00 \pm 0.14^{\pi}$ & 23.9 & $0.99 \pm 0.05^{x}$ & 24.2 & $1.06 \pm 0.11^{*}$ & 19.4 \\
\hline 40 & $1.07 \pm 0.07^{-}$ & 18.6 & $0.78 \pm 0.16^{\wedge}$ & 40.8 & $0.89 \pm 0.20^{\wedge}$ & 32.1 & $1.00 \pm 0.16$ & 24.0 \\
\hline 80 & $0.92 \pm 0.15^{\pi}$ & 29.8 & $0.55 \pm 0.14^{\pi x}$ & 57.7 & $0.52 \pm 0.08^{\pi x}$ & 60.5 & $0.78 \pm 0.13^{\pi x}$ & 40.2 \\
\hline 160 & $0.56 \pm 0.04^{\pi \pi}$ & 57.4 & $0.27 \pm 0.11^{\pi x}$ & 79.4 & $0.38 \pm 0.13^{\pi \pi}$ & 70.7 & $0.58 \pm 0.12^{x x}$ & 55.5 \\
\hline
\end{tabular}

Key: Conc = concentration $(\mu \mathrm{g} / \mathrm{mL}) ;$ Inhi = inhibition (\%); Values are means $\pm S D(n=6),{ }^{*} p<0.05$ vs control, ${ }^{* *} p$ $<0.01 \mathrm{vs}$ control; $W F=$ water fraction; $E F=$ ethyl acetate fraction; $M E=$ methanol extract; $T F=$ tannin fraction 
Table 5: Anticancer activity of different concentrations of various $P$. strobilacea infructescence solvent extracts and tannins on SH-SY-5Y cell line

\begin{tabular}{|c|c|c|c|c|c|c|c|c|c|c|c|}
\hline \multirow[t]{2}{*}{ Conc } & \multicolumn{2}{|l|}{ WF } & \multirow[t]{2}{*}{ Conc } & \multicolumn{2}{|l|}{ EF } & \multirow[t]{2}{*}{ Conc } & \multicolumn{2}{|l|}{ MF } & \multirow[t]{2}{*}{ Conc } & \multicolumn{2}{|l|}{ TF } \\
\hline & $\begin{array}{c}O D_{570 \mathrm{~nm}} \\
0.110 \pm 0.009\end{array}$ & $\frac{\operatorname{lnh} i}{\text { nil }}$ & & $\begin{array}{c}O D_{570 \mathrm{~nm}} \\
0.110 \pm 0.009\end{array}$ & $\begin{array}{l}\text { Inhi } \\
\text { nil }\end{array}$ & & $\begin{array}{c}O D_{570 \mathrm{~nm}} \\
0.171 \pm 0.006\end{array}$ & $\begin{array}{c}\frac{\operatorname{Inh} i}{\mathrm{nil}} \\
\end{array}$ & & $\frac{O D_{570 \mathrm{~nm}}}{0.212 \pm 0.016}$ & $\frac{\operatorname{lnh} i}{\text { nil }}$ \\
\hline 10 & $0.101 \pm 0.007$ & 5.3 & 15 & $0.094 \pm 0.021$ & 11.6 & 10 & $0.120 \pm 0.034^{\pi}$ & 30.1 & 25 & $0.097 \pm 0.016^{\pi *}$ & 54.0 \\
\hline 20 & $0.097 \pm 0.015$ & 8.8 & 30 & $0.067 \pm 0.020^{\pi}$ & 37.5 & 20 & $0.098 \pm 0.020^{\mathrm{x}}$ & 42.7 & 50 & $0.090 \pm 0.008^{\mathrm{x}}$ & 57.3 \\
\hline $\begin{array}{l}40 \\
80 \\
160\end{array}$ & $\begin{array}{l}0.086 \pm 0.026^{*} \\
0.042 \pm 0.013^{* *} \\
0.021 \pm 0.012^{* *}\end{array}$ & $\begin{array}{l}19.3 \\
60.4 \\
80.3\end{array}$ & $\begin{array}{c}60 \\
120 \\
240\end{array}$ & $\begin{array}{l}0.058 \pm 0.022^{n x} \\
0.024 \pm 0.033^{* \pi} \\
0.040 \pm 0.025^{* \pi}\end{array}$ & $\begin{array}{l}43.5 \\
45.4 \\
77.9\end{array}$ & $\begin{array}{c}40 \\
80 \\
160\end{array}$ & $\begin{array}{l}0.070 \pm 0.012^{* *} \\
0.063 \pm 0.015^{* *} \\
0.023 \pm 0.015^{* *}\end{array}$ & $\begin{array}{l}59.2 \\
63.4 \\
86.3\end{array}$ & $\begin{array}{l}100 \\
200 \\
400\end{array}$ & $\begin{array}{l}0.040 \pm 0.036 \\
0.035 \pm 0.021 \\
0.031 \pm 0.009^{* *}\end{array}$ & $\begin{array}{l}81.2 \\
83.6 \\
85.6\end{array}$ \\
\hline
\end{tabular}

Key: Conc $=$ concentration $(\mu \mathrm{g} / \mathrm{mL})$; Inhi $=$ inhibition (\%); Values are means $\pm S D(n=6),{ }^{*} p<0.05$ vs control, ${ }^{* *} p$ $<0.01 \mathrm{vs} \mathrm{control;} W F=$ water fraction; $E F=$ ethyl acetate fraction; $M E=$ methanol extract; $T F=$ tannin fraction

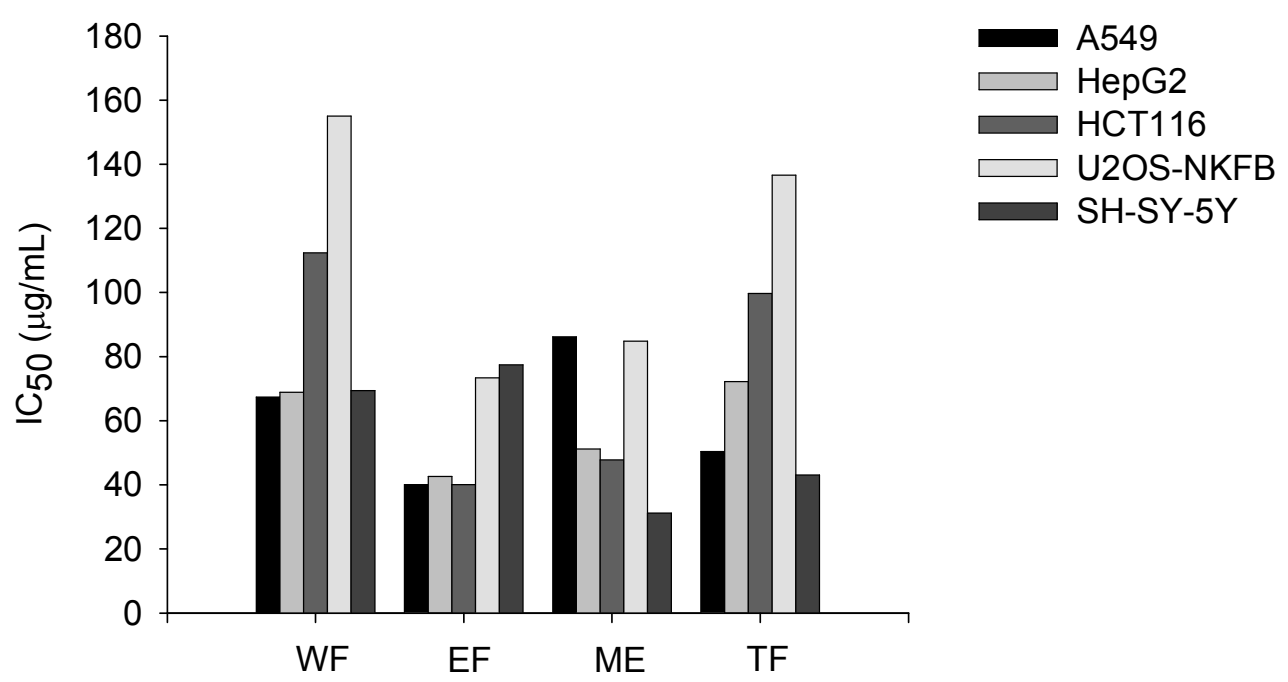

Figure 2: Anticancer activity of various solvent extracts and tannins of $P$. strobilacea infructescence on A549, HepG2, HCT116, U2OS-NKFB and SH-SY-5Y cell lines. Key: WF = water fraction; EF = ethyl acetate fraction; $\mathrm{ME}=$ methanol extract; $\mathrm{TF}=$ tannin fraction

\section{DISCUSSION}

Variations in the yields and phenolic contents of extracts are attributed to polarities of different compounds present in the PSI and such differences have been reported in the literature for the aerial parts of this plant [12] and other fruits [15].

The relationship between concentration of extracts and their cytotoxic effects on A549, HepG2, SH-SY-5Y, HCT116 and U2OS-NKFB cells was investigated by MTT assay. MTT is a yellow water-soluble tetrazolium salt. Metabolically active cells are able to convert the dye to water-insoluble dark blue formazan by reductive cleavage of the tetrazolium ring. The strong cytotoxic activity of ethyl acetate and methanol extracts from PSI may be attributed to the presence of specific components such as polyphenols and flavonoids of these extracts. Besides, some studies have shown that polyphenols and flavonoids are able to influence a variety of cell functions by modulating cell signalling [16], altering proliferation and cytotoxicity in cancer cell lines [17].

\section{CONCLUSION}

PSI ethyl acetate and methanol extracts possess cytotoxic effects on the in vitro cancer cell lines tested. The findings also demonstrate that the extracts have low $\mathrm{IC}_{50}$ values, and may be a potential source of pharmacologically useful products. Thus, the presence of potent cytotoxic compounds in this plant warrants further investigation.

\section{ACKNOWLEDGEMENT}

The authors are grateful to the Natural Science Foundation of Jiangsu, China (BK2012064) for financial support. 


\section{REFERENCES}

1. Yang SP, Yue JM. Discovery of structurally diverse and bioactive compounds from plant resources in China. Acta Pharmacol Sin 2012; 33: 1147-1158.

2. Geissman TA. Flavonoid compounds, tannins, lignins and related compounds. In: Florkin M, Stotz EH. (Eds). Pyrrole Pigments, Isoprenoid Compounds and Phenolic Plant Constituents; Elsevier Press, New York, USA 1963; $p 265$.

3. Greenberg ER, Baron JA. Tosteson TD. A clinical trial of antioxidant vitamins to prevent colorectal cancer. $N$ Engl J Med 1994; 331: 141-147.

4. Weng CJ, Yen GC. Chemopreventive effects of dietary phytochemicals against cancer invasion and metastasis: phenolic acids, monophenol, polyphenol, and their derivatives. Cancer Treat Rev 2012; 38: 7687.

5. Yang CS, Li G, Yang Z, Guan F, Chen A, Ju J. Cancer prevention by tocopherols and tea polyphenols. Cancer Lett 2013; 334: 79-85.

6. Northwest Institute of Botany CAS. Flora of the Qinling Mountains; Vol. 10, Science Press, Beijing, China 1970.

7. Tanaka T, Jiang ZH, Kouno I. Distribution of ellagic acid derivatives and a diarylheptanoid in wood of Platycarya strobilacea. Phytochemistry 1998; 47: 851-854.

8. Tanaka T, Kirihara S, Nonaka GI, Nishioka I. Tannins and related compounds. CXXIV. Five new ellagitannins, platycaryanins $A, B, C$, and $D$, and platycariin, and a new complex tannin, strobilanin, from the fruits and bark of Platycarya strobilacea SIEB et ZUCC., and biomimetic synthesis of C-glycosidic ellagitannins from glucopyranose-based ellagitannins. Chem Pharm Bull 1993; 41: 1708-1716.

9. Maeda H, Kakoki N, Ayabe M, Koga Y, Oribe Y, Matsuo $Y$, Tanaka $T$, Kouno $I$. ent-Eudesmane sesquiterpenoids, galloyl esters of the oak lactone precursor, and a 3-O-methylellagic acid glycoside from the wood of Platycarya strobilacea. Phytochemistry 2011; 72: 796-803.

10. Babu D, Lee JS, Park SY, Thapa D, Choi MK, Kim AR, Park YJ, Kim JA. Involvement of NK-KB in the inhibitory actions of Platycarya strobilacea on the TNF- $\alpha$-induced monocyte adhesion to colon epithelial cell and chemokine expression. Arch Pharm Res 2008; 31: 727-735.

11. Kim YH, Kim KH, Han CS, Yang HC, Park SH, Jang HI, Kim JW, Choi YS, Lee NH. Anti-wrinkle activity of Platycarya strobilacea extract and its application as a cosmeceutical ingredient. J Cosmet Sci 2010; 61: 211-224.

12. Choi YH, Chae SG, Kim JH, Kang S, Baek NI, Han JT. Isolation of an antifungal compound from aerial parts of Platycarya strobilacea. J Korean Soci Agric Biotechnol 2003; 46: 268-270.

13. Djeridane $A$, Yousfi $M$, Nadjemi $B$, Boutassouna $D$, Stocher $P$, Vidal N. Antioxidant activity of some Algerian medicinal plants extracts containing phenolic compounds. Food Chem 2006; 97: 654-660.

14. Alley MC, Scudiero DA, Monkes A, Hursey ML, Czerwinski MJ, Fine DL, Abbott BJ, Mayo JG, Shoemaker RH, Boyd MR. Feasibility of drug screening with panel of human tumor cell lines using a microculture tetrazolium assay. Cancer Res 1988; 48: 589-601.

15. Negi PS, Chauhan AS, Sadia GA; Rohinishree YS, Ramteke RS. Antioxidant and antibacterial activities of various seabuckthorn (Hippophae rhamnoides L.) seed extracts. Food Chem 2005; 92: 119-124.

16. Santangelo $C$, Vari $R$, Scazzocchio $B$, Di Benedetto $R$, Filesi C, Masella R. Polyphenols, intracellular signalling and inflammation. Ann Ist Super Sanita 2007; 43: 394-405.

17. Kuntz S, Wenzel U, Daniel H. Comparative analysis of effects of flavonoids on proliferation, cytotoxicity and apoptosis in human colon cancer cell lines. Eur J Nutr 1999; 38: 133-142. 